\title{
Counterregulation in Type 2 (non-insulin-dependent) diabetes mellitus. Normal endocrine and glycaemic responses, up to ten years after diagnosis
}

\author{
S. R. Heller ${ }^{1}$, I.A. Macdonald ${ }^{2}$ and R. B. Tattersall ${ }^{1}$ \\ Departments of ${ }^{1}$ Medicine and ${ }^{2}$ Physiology and Pharmacology, University Hospital and Nottingham University Medical School, \\ Queen's Medical Centre, Nottingham, UK
}

\begin{abstract}
Summary. We have examined hormonal and metabolic responses to insulin-induced hypoglycaemia in 10 Type 2 (noninsulin-dependent) diabetic patients treated with tablets and 10 age, sex and weight matched control subjects. Diabetic patients were under $110 \%$ ideal body weight, had no autonomic neuropathy and were well controlled $\left(\mathrm{HbA}_{1}, 7.1 \pm\right.$ $0.2 \%$ ). After the diabetic patients were kept euglycaemic by an overnight insulin infusion, hypoglycaemia was induced in both groups by intravenous insulin at $30 \mathrm{mU} \cdot \mathrm{m}^{-2} \cdot \mathrm{min}^{-1}$ for $60 \mathrm{~min}$ and counterregulatory responses measured for $150 \mathrm{~min}$. There were no significant differences between diabetic patients and control subjects in the rate of fall $(3.3 \pm 0.3$ vs $\left.4.0 \pm 0.3 \mathrm{mmol} \cdot 1^{-1} \cdot \mathrm{h}^{-1}\right)$, nadir $(2.4 \pm 0.2$ vs $2.3 \pm$
\end{abstract}

$0.1 \mathrm{mmol} / \mathrm{l})$ and rate of recovery $(0.027 \pm 0.002$ vs $0.030 \pm$ $\left.0.003 \mathrm{mmol} \cdot 1^{-1} \cdot \mathrm{min}^{-1}\right)$ of blood glucose. Increments of glucagon $(60.5 \pm 5.7$ vs $70 \pm 9.2 \mathrm{ng} / 1)$ and adrenaline $(1.22 \pm 0.31$ vs $1.45 \pm 0.31 \mathrm{nmol} / 1$ ) were similar in both groups. When tested using this model, patients with Type 2 diabetes, without microvascular complications and taking oral hypoglycaemic agents show no impairment of the endocrine response and blood glucose recovery following hypoglycaemia.

Key words: Type 2 (non-insulin-dependent) diabetes mellitus, counterregulation, hypoglycaemia, glucagon, adrenaline, pancreatic polypeptide.
Patients with Type 1 (insulin-dependent) diabetes mellitus acquire an impaired glucagon response to hypoglycaemia within two years of diagnosis $[1,2]$. However, blood glucose recovery is relatively unaffected because normal adrenaline release largely compensates for diminished glucagon secretion [3]. Some Type 1 patients with a longer duration of diabetes show impaired responses of both glucagon and adrenaline and may then be subject to severe attacks of hypoglycaemia, especially during intensified therapy $[4,5]$.

Increasingly intensive therapies are being recommended in Type 2 (non-insulin-dependent) diabetes with targets such as maintenance of fasting blood glucose below $6 \mathrm{mmol} / 1$ [6]. Not only is hypoglycaemia unexpected and probably more distressing to older people, but it is arguably dangerous to those with cerebral or coronary atherosclerosis. It is therefore important to establish whether counterregulation is intact in the Type 2 diabetic patient. Two studies have suggested normal counterregulation $[7,8]$ while a third showed impaired responses, not only of glucagon and adrenaline but also cortisol and growth hormone [9]. These differences might be explained by the variety of ways in which hypoglycaemia was induced, but a more im- portant confounding factor is that diabetic and control groups rarely started at the same level of blood glucose.

The aim of our study was to compare glucose counterregulation in 10 well-controlled, tablet treated diabetic patients and 10 sex, weight and age matched control subjects, ensuring that both groups were normoglycaemic at the beginning of the experiment.

\section{Subjects and methods}

\section{Patients}

The study cohort was composed of eight men and two women, all less than $110 \%$ ideal body weight with a mean age of 42 years (range 26-61 years) (Table 1). At diagnosis all the patients had been symptomatic with a random blood glucose above $11 \mathrm{mmol} / 1$. All were receiving sulphonylureas; in addition two were taking metformin. They had a mean known duration of diabetes of 46 months (range 15-120 months) and all but one, had an $\mathrm{HbA}_{1}$ within the normal range $(5.0-7.5 \%)$. No patient had evidence of autonomic neuropathy as measured by heart rate variation on deep breathing, Valsalva manoeuvre and standing [10]. No patient had retinopathy or other diabetic complications. Control subjects, who had no family history of diabetes mellitus, were matched for age, sex and weight. All sub- 
Table 1. Clinical details of subjects

\begin{tabular}{|c|c|c|c|c|c|c|c|c|c|}
\hline \multicolumn{5}{|c|}{ Diabetic patients } & \multirow{2}{*}{$\begin{array}{l}\text { Duration } \\
\text { of diabetes } \\
\text { (months) }\end{array}$} & \multirow[t]{2}{*}{ Treatment } & \multirow[t]{2}{*}{$\begin{array}{l}\mathrm{HbA}_{1} \\
(\%)\end{array}$} & \multicolumn{2}{|c|}{$\begin{array}{l}\text { C peptide } \\
\text { (after i.v.glucagon) }\end{array}$} \\
\hline & Sex & $\begin{array}{l}\text { Age } \\
\text { (years) }\end{array}$ & $\begin{array}{l}\text { Weight } \\
\text { (kg) }\end{array}$ & $\begin{array}{l}\text { BMI } \\
\left(\mathrm{kg} / \mathrm{m}^{2}\right)\end{array}$ & & & & $\begin{array}{l}0 \min \\
(\mathrm{mmol} / \mathrm{l})\end{array}$ & $\begin{array}{l}6 \mathrm{~min} \\
(\mathrm{mmol} / \mathrm{l})\end{array}$ \\
\hline 1 & $\mathbf{M}$ & 31 & 83 & 25.0 & 18 & glibenclamide & 6.5 & 0.50 & 0.80 \\
\hline 2 & M & 49 & 68 & 22.2 & 15 & glibenclamide & 6.2 & 0.27 & 0.60 \\
\hline 3 & M & 47 & 56 & 18.7 & 20 & glibenclamide/metformin & 9.1 & 0.16 & 0.26 \\
\hline 4 & M & 50 & 71 & 24.6 & 42 & glibenclamide & 6.6 & 0.60 & 1.25 \\
\hline 5 & M & 61 & 82 & 24.0 & 60 & glibenclamide/metformin & 7.5 & 0.65 & 1.00 \\
\hline 6 & M & 50 & 78 & 23.0 & 24 & glibenclamide & 7.1 & 0.40 & 0.75 \\
\hline 7 & $\mathbf{M}$ & 33 & 86 & 23.3 & 60 & glibenclamide & 6.8 & 0.45 & 1.10 \\
\hline 8 & $\mathrm{~F}$ & 26 & 55 & 20.4 & 84 & glibenclamide & 6.7 & 0.36 & 0.70 \\
\hline 9 & $\mathrm{M}$ & 46 & 102 & 24.8 & 120 & chlorpropamide & 7.5 & 0.70 & 1.70 \\
\hline 10 & $\mathrm{~F}$ & 26 & 65 & 22.5 & 18 & chlorpropamide & 6.8 & 0.40 & 0.60 \\
\hline \multicolumn{2}{|c|}{$\operatorname{Mean}( \pm$ SEM $)$} & $42 \pm 4$ & $74 \pm 5$ & $22.9 \pm 0.6$ & $46 \pm 11$ & & $7.1 \pm 0.3$ & $0.45 \pm 0.05$ & $0.88 \pm 0.13$ \\
\hline \multicolumn{10}{|c|}{ Control subjects $(8 \mathrm{M}, 2 \mathrm{~F})$} \\
\hline \multicolumn{2}{|c|}{$\operatorname{Mean}( \pm \mathrm{SEM})$} & $41 \pm 3$ & $73 \pm 3$ & $23.2 \pm 0.7$ & & & $5.9 \pm 0.2$ & & \\
\hline
\end{tabular}

jects gave written consent for the study which was approved by the Nottingham University Hospital ethical committee.

\section{Methods}

The diabetic patients' hypoglycaemic medication was stopped $72 \mathrm{~h}$ before the study and blood glucose controlled with multiple injections of Actrapid $\mathrm{MC}$ insulin (Novo Industri $\mathrm{A} / \mathrm{S}$, Copenhagen, Denmark) until admission to hospital, the evening before the study. Blood glucose was maintained between 4 and $6 \mathrm{mmol} / 1$ overnight by a variable infusion of Actrapid $\mathrm{MC}$ insulin (at a concentration of $15 \mathrm{U}$ in $58 \mathrm{ml}$ of $0.9 \%$ sodium chloride to which $2 \mathrm{ml}$ of the patient's own blood was added) administered by an infusion pump (Treonic IP3, Vicker's Medical, Basingstoke, UK) into a forearm vein.

At 07.30 hours a cannula was placed in a brachial vein of the opposite arm, kept patent by a slow infusion of saline and used for intermittent blood sampling. Diabetic patients and control subjects were fasted overnight and control subjects were recumbent for $1 \mathrm{~h}$ before the start of the study.

After two basal blood samples, $15 \mathrm{~min}$ apart, insulin was infused for $60 \mathrm{~min}$ at $30 \mathrm{mU} \cdot \mathrm{m}^{-2} \cdot \mathrm{min}^{-1}$; and then between 60 and $150 \mathrm{~min}$. diabetic patients received insulin at a rate half that required to maintain their blood glucose in the hour before the study [11]. Blood samples were taken every $15 \mathrm{~min}$ and blood glucose measured at the bedside with a glucose oxidase method on a glucose analyser (Yellow Springs Instruments, Yellow Springs, Ohio, USA). Two ml blood were added to iced tubes containing $3 \mathrm{~mol} / 1$ perchloric acid; after centrifugation, the supernatant was placed on ice for measurement of beta-hydroxybutyrate, later the same day, using a continuous flow fluorimetric method [12]. Two $\mathrm{ml}$ blood were placed in EDTA tubes for centrifugation and measurement of plasma non-esterified fatty acids (NEFA) by an enzymatic method (NEFAC, Wako Chemicals GmbH, Neuss, FRG). The rest of the sample was added to iced heparinised tubes, centrifuged and the plasma deep frozen before assay. Plasma for glucagon and pancreatic polypeptide estimation was added to tubes containing 1500 units of aprotonin (Trasylol, Bayer AG, Leverkusen, FRG) before storage. Radioimmunoassays were used to measure C-terminal glucagon [13], pancreatic polypeptide [14] and insulin [15]. Plasma for catecholamine estimation was added to $100 \mu \mathrm{l}$ of EGTA-glutathione before storage at $-80^{\circ} \mathrm{C}$. Catecholamines were measured by HPLC with electrochemical detection [16]. Cortisol, growth hormone and C-peptide [17] were measured by radioimmunoassay using standard commercial kits. Stable $\mathrm{HbA}_{1}$ was measured by an electrophoretic method on cellulose acetate membrane [18].

Heart rate (from a cardiac monitor) and blood pressure (BP) (by direct auscultation of the brachial artery) were recorded every $15 \mathrm{~min}$.

\section{Statistical analysis}

The results are expressed as means \pm SEM and basal values are those obtained at time 0 . Statistical analysis was performed with standard analysis of variance (ANOVA) methods. Where F-tests revealed significant treatment by time interactions, the exact nature of these differences was determined by Student's t-tests on the contrasts in the group means. Most of the analysis was done with the statistical package Genstat [19].

\section{Results}

\section{Blood glucose and plasma insulin}

There were no differences (Fig. 1) between Type 2 diabetic patients and control subjects in rate of fall $(3.3 \pm$ 0.3 vs $\left.4.0 \pm 0.3 \mathrm{mmol} \cdot 1^{-1} \cdot \mathrm{h}^{-1}\right)$, nadir $(2.4 \pm 0.2$ vs $2.3 \pm 0.1 \mathrm{mmol} / \mathrm{l})$ and rate of recovery $(0.027 \pm 0.002 \mathrm{vs}$ $0.030 \pm 0.003 \mathrm{mmol} \cdot 1^{-1} \cdot \mathrm{min}^{-1}$ ) of blood glucose. The nadir was reached after a similar time in diabetic patients $(55.5 \pm 2 \mathrm{~min})$ and control subjects $(52 \pm 4 \mathrm{~min})$.

Basal insulin levels were similar in diabetic patients and control subjects $(14.3 \pm 1.5$ vs $9.4 \pm 1.3 \mathrm{mU} / \mathrm{l})$ and rose similarly during insulin infusion $(51 \pm 2.6$ vs $49 \pm$ $3.9 \mathrm{mU} / 1$ at $60 \mathrm{~min}$ ). Between 60 and $120 \mathrm{~min}$ there was no significant difference between plasma insulin concentrations of the two groups.

\section{Glucagon}

Basal levels were similar (Fig. 2) in diabetic patients and control subjects $(78 \pm 3.6 \mathrm{vs} 76 \pm 5.8 \mathrm{ng} / \mathrm{l})$ and rose similarly in both groups during hypoglycaemia (134 \pm 7.1 vs $133 \pm 13.6 \mathrm{ng} / \mathrm{l})$ but with a peak at a mean of $72 \pm 3.0 \mathrm{~min}$ in the diabetic patients compared to $63 \pm$ $3.7 \mathrm{~min}(p=\mathrm{NS})$ in the control subjects. Glucagon levels in control subjects returned to baseline by $105 \mathrm{~min}$ $(82 \pm 6.9 \mathrm{ng} / 1)$. However, in the diabetic patients, plasma glucagon concentrations declined from their peak value but remained above baseline throughout the recovery period $(95 \pm 4.5 \mathrm{ng} / 1)$. 

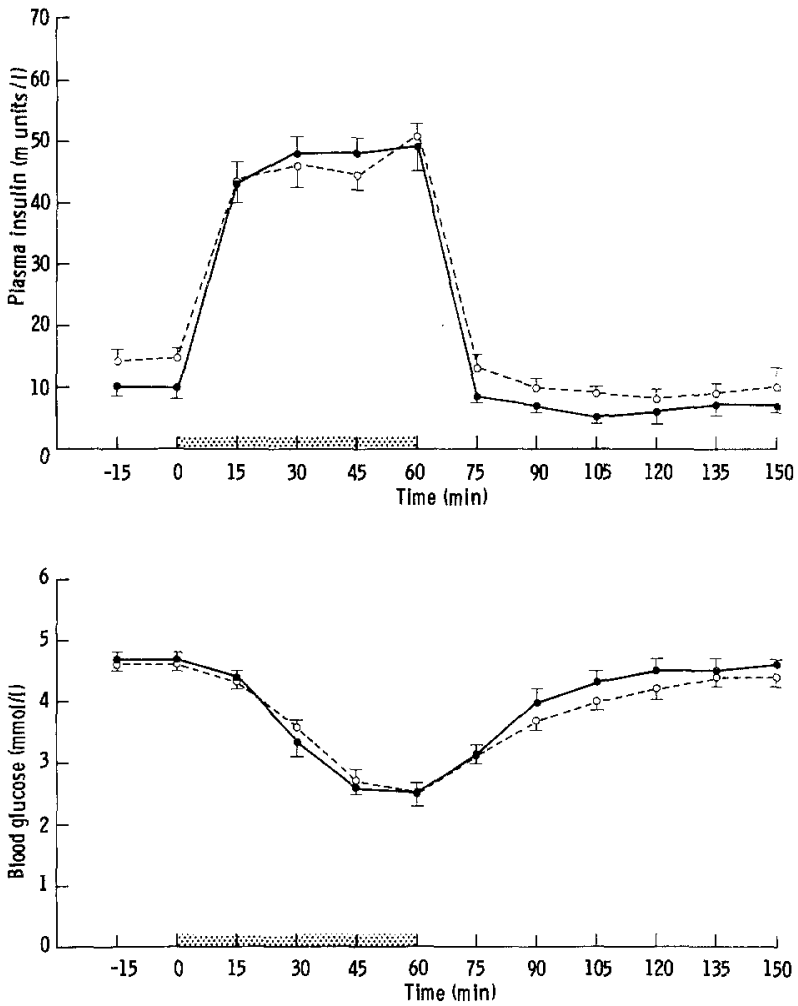

Fig. 1. Plasma insulin (top panel) and blood glucose (bottom panel) concentrations of 10 Type 2 (non-insulin-dependent) diabetic patients $(\mathrm{O}-\mathrm{O})$ and 10 control subjects $(-)$ ) before, during and after the infusion of insulin $\left(30 \mathrm{mU} \cdot \mathrm{m}^{-2} \cdot \mathrm{min}^{-1}\right.$ for $\left.60 \mathrm{~min}\right)$. The shaded area represents the duration of the insulin infusion. None of the differences are statistically different

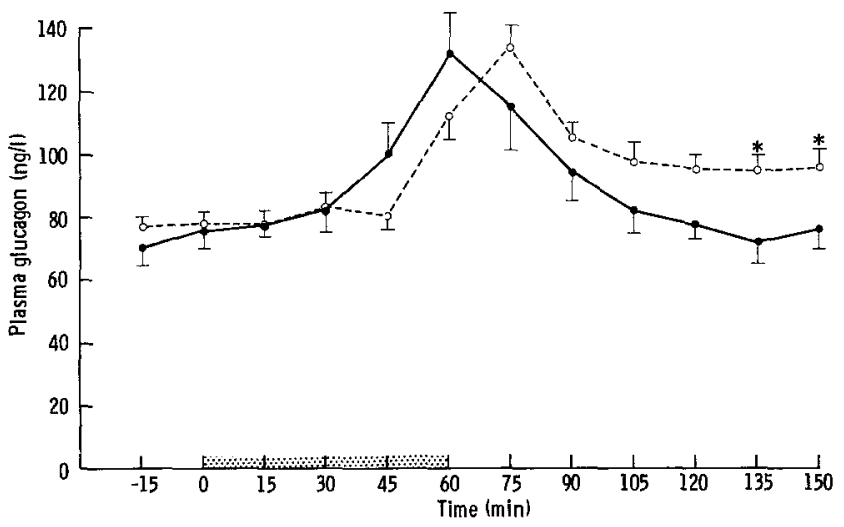

Fig. 2. Plasma glucagon concentrations of 10 Type 2 diabetic patients $\left(\mathrm{O}_{--} \mathrm{O}\right)$ and 10 control subjects $(-)$ before, during and after the infusion of insulin $\left(30 \mathrm{mU} \cdot \mathrm{m}^{-2} \cdot \mathrm{min}^{-1}\right.$ for $\left.60 \mathrm{~min}\right)$. The shaded area represents the duration of the insulin infusion. The asterisk denotes values for Type 2 diabetic patients significantly greater than for controls, $p<0.05$

\section{Adrenaline}

Basal levels (Fig. 3) were similar in diabetic patients and control subjects $(0.19 \pm 0.03$ vs $0.16 \pm 0.03 \mathrm{nmol} / 1)$. Peak levels during hypoglycaemia were also similar $(1.25 \pm 0.37$ vs $1.42 \pm 0.3 \mathrm{nmol} / 1)$ although the rise in the diabetic patients occurred slightly later.

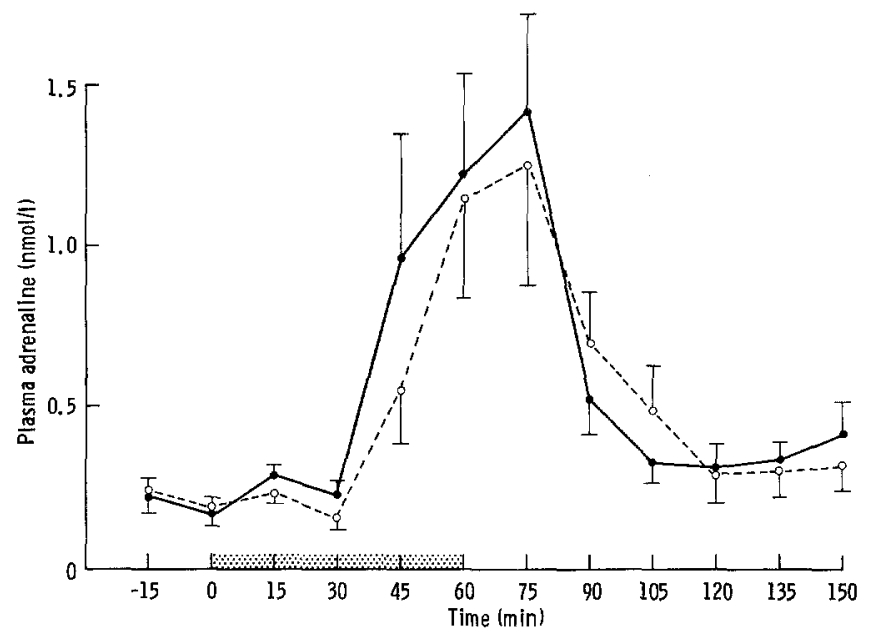

Fig. 3. Plasma adrenaline concentrations of 10 Type 2 diabetic patients $\left(\mathrm{O}_{-} \mathrm{O}\right)$ and 10 control subjects $(-)$ ) before, during and after the infusion of insulin $\left(30 \mathrm{mU} \cdot \mathrm{m}^{-2} \cdot \mathrm{min}^{-1}\right.$ for $\left.60 \mathrm{~min}\right)$. The shaded area represents the duration of the insulin infusion

\section{Cortisol and growth hormone}

Basal levels of cortisol were similar in diabetic patients and control subjects $(368 \pm 42$ vs $358 \pm 41 \mathrm{nmol} / \mathrm{l})$ and reached a similar peak at $90 \mathrm{~min}(622 \pm 67$ vs $581 \pm$ $59 \mathrm{nmol} / 1)$. Basal growth hormone levels were the same in diabetic patients and control subjects $(4.3 \pm 1.7$ vs $4.2 \pm 2.1 \mathrm{mU} / 1$ ) with equivalent peaks at $90 \mathrm{~min}$ $(38.7 \pm 8$ vs $34.7 \pm 10 \mathrm{mU} / 1)$.

\section{Pancreatic polypeptide}

Levels of pancreatic polypeptide at baseline were similar (Fig. 4) in both diabetic patients and control subjects $(61 \pm 15$ vs $43 \pm 4 \mathrm{ng} / 1)$, but peak concentrations of diabetic patients were significantly greater than that of control subjects $(479 \pm 87$ vs $253 \pm 49 \mathrm{ng} / 1, p<0.05)$.

\section{Beta-hydroxybutyrate and non esterified fatty acids}

Diabetic patients and control subjects had similar basal levels (Fig. 5) of hydroxybutyrate $(0.63 \pm 0.2$ vs $0.57 \pm 0.14 \mathrm{mmol} / \mathrm{l})$ and showed similar reductions during insulin infusion $(0.23 \pm 0.07$ vs $0.16 \pm$ $0.03 \mathrm{mmol} / 1$ at $60 \mathrm{~min}$ ). The diabetic patients had a significantly greater rise in hydroxybutyrate concentrations during the last $45 \mathrm{~min}$ of the experiment.

Basal levels of plasma NEFA (Fig. 5) were similar $(0.41 \pm 0.04$ vs $0.50 \pm 0.05 \mathrm{mmol} / \mathrm{l})$ and were reduced similarly after $45 \mathrm{~min}$ of the insulin infusion $(0.21 \pm$ 0.02 vs $0.21 \pm 0.02 \mathrm{mmol} / 1$ ). From $75 \mathrm{~min}$ to the end of the recovery period the concentrations of NEFA were significantly higher in the diabetic patients.

\section{Heart rate and blood pressure}

Basal heart rate was similar in diabetic patients and control subjects $[65 \pm 2.2$ vs $69 \pm 3.6$ beats per minute 


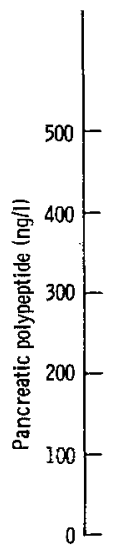

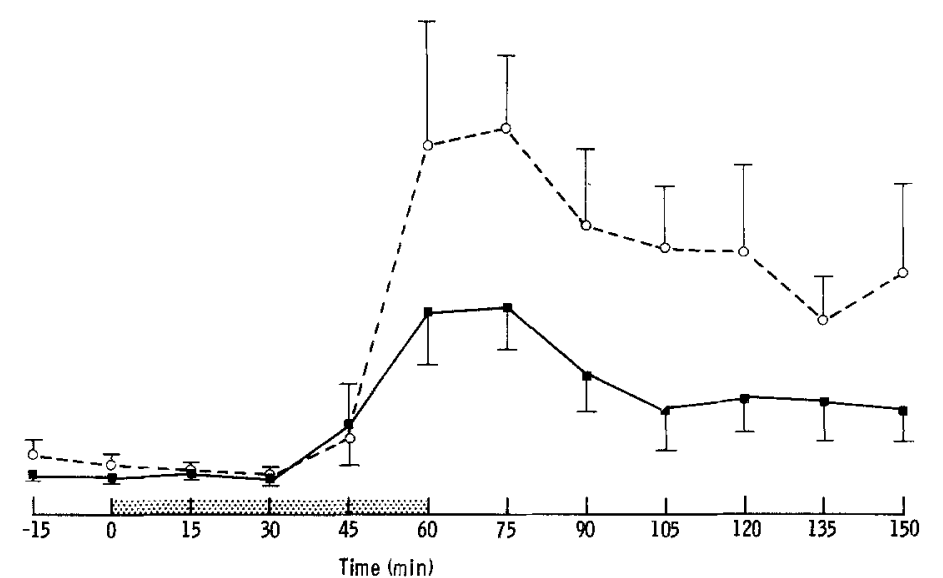

Fig.4. Plasma pancreatic polypeptide concentrations of 10 Type 2 diabetic patients $\left(\mathrm{O}_{-} \mathrm{O}^{\mathrm{O}}\right.$ ) and 10 control subjects $(-)$ before, during and after the infusion of insulin $\left(30 \mathrm{mU} \cdot \mathrm{m}^{-2} \cdot \mathrm{min}^{-1}\right.$ for $\left.60 \mathrm{~min}\right)$. The shaded area represents the duration of the insulin infusion
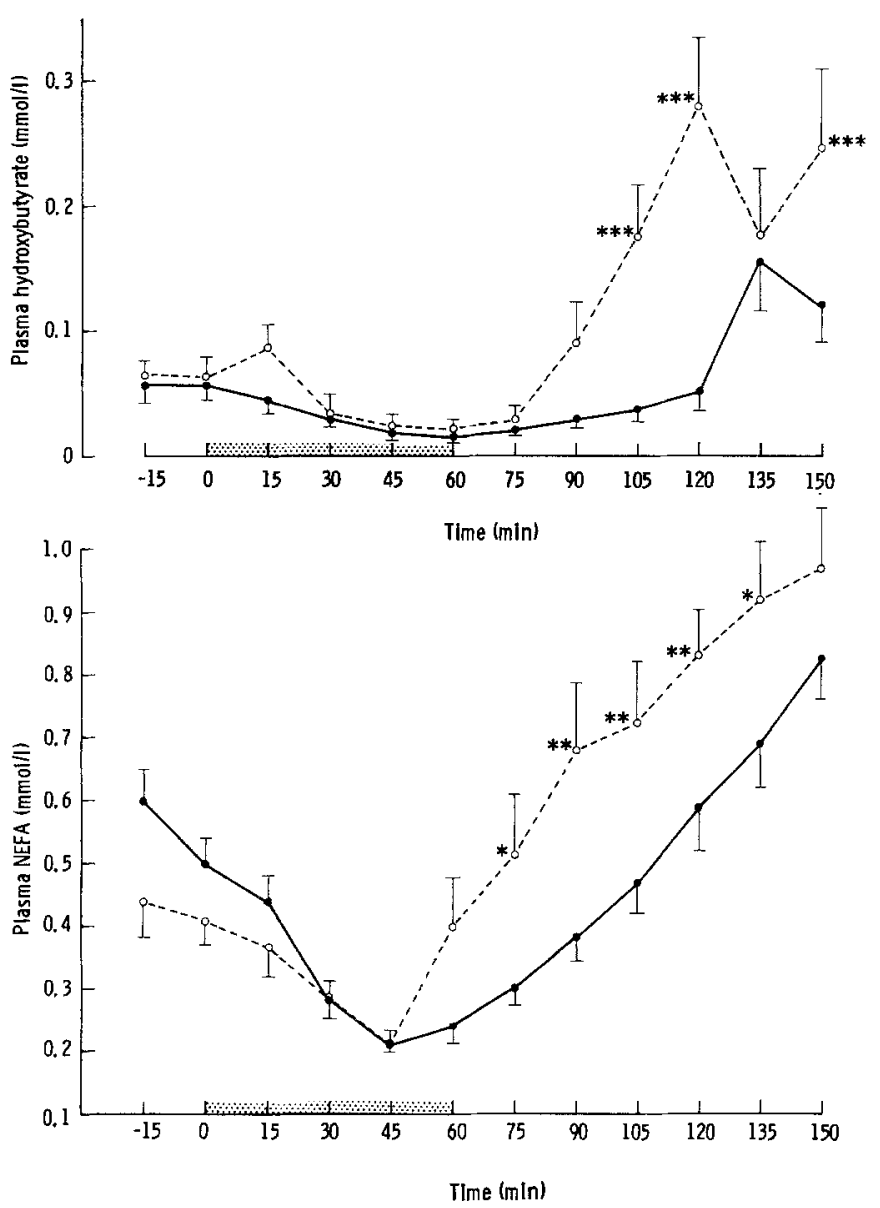

Fig.5. Plasma hydroxybutyrate (top panel) and non-esterified fatty acid (NEFA, bottom panel) concentrations of 10 Type 2 diabetic patients $(\mathrm{O}-\mathrm{O})$ and 10 control subjects $(-)$, before, during and after the infusion of insulin $\left(30 \mathrm{mU} \cdot \mathrm{m}^{-2} \cdot \mathrm{min}^{-1}\right.$ for $\left.60 \mathrm{~min}\right)$. The shaded area represents the duration of the insulin infusion. Significantly greater values for Type 2 diabetic patients compared to control subjects are denoted by ${ }^{*} p<0.05,{ }^{* *} p<0.01$, *** $p<0.001$

(bpm)]. Heart rate during hypoglycaemia was similar in both groups $(70 \pm 2.4$ at $45 \mathrm{~min}$ vs $76 \pm 5.8$ at $60 \mathrm{~min}$, $\mathrm{bpm})$, but only increased significantly in the diabetic group $(p<0.05)$.

Basal systolic blood pressure (BP) was similar in both groups $(130 \pm 5$ vs $124 \pm 4 \mathrm{~mm} \mathrm{Hg})$ and did not change during the experiment. Diabetic patients and control subjects had a similar basal diastolic BP $(82 \pm$ 2.5 vs $83 \pm 2.1 \mathrm{~mm} \mathrm{Hg}$ ) which fell significantly $(p<$ 0.01 ) during hypoglycaemia to $75 \pm 3.5$ vs $76 \pm$ $2.9 \mathrm{~mm} \mathrm{Hg}$ at $60 \mathrm{~min}$.

\section{Discussion}

We have shown that in response to insulin-induced hypoglycaemia, well-controlled Type 2 diabetic patients treated with oral hypoglycaemic agents and without microvascular complications have a similar rise in counterregulatory hormones and recovery of blood glucose when compared to normal subjects. There have been few specific studies of the counterregulatory response in Type 2 diabetes. Some have included both patients with Type 1 and Type 2 diabetes [20,21] but as they were not separated in the analysis it is impossible to draw conclusions. In 10 Type 2 diabetic patients, all taking oral hypoglycaemic agents, Boden et al. [7] observed similar increments in adrenaline and glucagon to those in their control group. However, as blood glucose was imperfectly controlled before the study, basal glucagon levels in the diabetic patients were significantly greater than in control subjects. Polonsky et al. [8] reported a normal rise of glucagon and adrenaline following hypoglycaemia induced by an intravenous infusion of insulin in 8 Type 2 diabetic patients. As in the study of Boden et al. [7], basal blood glucose concentrations were higher in the diabetic patients than control subjects and basal levels of glucagon and adrenaline not reported.

The importance of controlling blood glucose before inducing hypoglycaemia is emphasised by Levitt et al. [22]. When hypoglycaemia was induced in 5 Type 2 diabetic patients (without autonomic neuropathy) without any attempt to control blood glucose before induction of hypoglycaemia, the glucagon response was apparently impaired. However, after overnight blood glucose control with intravenous insulin in the same patients, glucagon response to hypoglycaemia was normal. Probably the main effect of the overnight 
insulin infusion was to ensure that both diabetic and control groups received an identical hypoglycaemic stimulus, i.e. a similar decrement and nadir of blood glucose.

In contrast, an impaired counterregulatory response to hypoglycaemia was observed by Bolli et al. [9], who gave a bolus of subcutaneous insulin to 13 non-obese Type 2 diabetic patients after maintaining blood glucose between 4.5 and $5.5 \mathrm{mmol} / 1$ for $10 \mathrm{~h}$. Basal levels were similar to control subjects but the diabetic patients had impaired glucagon, adrenaline, growth hormone and cortisol responses. This resulted in reduced hepatic glucose production, but only slightly slower blood glucose recovery, because of a simultaneous reduction in glucose utilisation.

The differences between our results and those of Bolli et al. [9] may be due to their use of subcutaneous insulin which resulted in a slower fall of blood glucose and a higher nadir of $3.4 \mathrm{mmol} / \mathrm{l}$. This more prolonged stimulus to counterregulatory hormone secretion might have allowed minor abnormalities to become apparent which were masked during hypoglycaemia induced by intravenous insulin. However, our model of hypoglycaemia has been previously used to test Type 1 diabetic patients [11]. The normal glucagon response in our patients, all with a duration of diabetes greater than 15 months, contrasts with the impaired response in most Type 1 diabetic patients of comparable duration $[2,11]$.

An impaired glucagon response to hypoglycaemia in Type 1 diabetic patients was first described 13 years ago [1] but the mechanism of the defect in the A cell remains unknown [23]. The original suggestion that it is a consequence of early autonomic neuropathy [24, 25] seems unlikely since the impaired glucagon response develops within 2 years of diagnosis, when cardiovascular tests of autonomic function are normal and when there are no other signs of microvascular complications. Furthermore, some patients with Type 2 diabetes and symptoms and signs of autonomic neuropathy have a normal glucagon response [8, 22].

Samols et al. have proposed that normally, A cell glucagon secretion is inhibited by insulin released from adjacent $B$ cells by a paracrine effect [26]. As hypoglycaemia suppresses endogenous insulin secretion, glucagon release is then disinhibited. Since Type 1 diabetic patients cannot secrete insulin, it was argued that this would prevent an appropriate glucagon response during hypoglycaemia [27]. However, this theory has been challenged by the demonstration of a normal glucagon response in patients with a short duration of Type 1 diabetes, who have no endogenous insulin secretion [28].

Our observations would imply an alternative explanation, i.e. that the impaired glucagon response is a consequence of chronic insulin therapy. Insulin inhibits glucagon release $[29,30]$ and although acute hyperinsulinaemia has no effect on glucagon response to hy- poglycaemia [28], the effect of chronic hyperinsulinaemia has never been properly tested. The impaired glucagon response in the Type 2 diabetic patients studied by Bolli et al. [9], at first sight supports our hypothesis since most ( 8 of 13) were insulin treated. However, there were no differences between the patients treated with diet or tablets, and those receiving insulin. The patients with Type 2 diabetes studied by Polonsky et al. [8] included 4 who were insulin treated, 2 of whom had a normal glucagon response. Thus, the available evidence is scanty and conflicting. It will need a prospective study, in which Type 2 diabetic patients are randomised to receive insulin or tablets, with counterregulatory responses measured both before and after at least 12 months of treatment to determine whether insulin treatment per se causes impaired counterregulation.

During blood glucose recovery, plasma NEFA and hydroxybutyrate rose to higher levels in the diabetic patients. This was also observed by Bolli et al. [9] and was attributed to insulin resistance in the presence of increased catecholamines. Alternatively, Type 2 diabetic patients may be more sensitive to the lipolytic and ketogenic actions of adrenaline than normal control subjects. Berk et al. [31] showed that these effects of adrenaline (unlike the glycaemic response) were not limited by enhanced insulin secretion. Furthermore, they demonstrated an exaggerated ketogenic response in their Type 1 diabetic patients in contrast to control subjects, although there was no difference in the lipolytic response.

An unexpected finding was that plasma glucagon levels did not return to baseline in the diabetic group, as also found by Boden et al. [7]. Furthermore, pancreatic polypeptide responses were greater in the diabetic patients, in contrast to Levitt et al., who observed similar increases in Type 2 patients without autonomic neuropathy and control subjects, following hypoglycaemia [32]. Adrenaline stimulates glucagon secretion [33]; there may be increased adrenergic sensitivity in the pancreatic A cells of patients with Type 1 diabetes [31]. Release of pancreatic polypeptide is predominately under vagal control [34], but also occurs following beta adrenergic stimulation [35]. While increased adrenergic sensitivity has yet to be demonstrated in the pancreatic islet cells of Type 2 diabetic patients, such a mechanism might account for our observations.

In conclusion, the blood glucose and acute endocrine response to hypoglycaemia induced by an intravenous insulin infusion was the same in 10 well controlled Type 2 diabetic patients and 10 age, sex and weight matched control subjects. Thus, using this model of hypoglycaemia, Type 2 diabetic patients on oral hypoglycaemic agents have different responses to those of Type 1 diabetic patients of similar duration, although the reason is unexplained.

Acknowledgements. We would like to thank Professor K.D.Buchanan for measuring plasma glucagon and pancreatic polypeptide, Pro- 
fessor K.G.M.M. Alberti for measuring C-peptide and Mr. N. Smith and Mr. C. Selby of the City Hospital, Nottingham for measuring intermediary metabolites, insulin, growth hormone and cortisol. We gratefully acknowledge the financial assistance of the Special Trustees, Nottingham Hospitals. SRH was supported by the British Diabetic Association.

\section{References}

1. Gerich JE, Langlois M, Noacco C, Karam JH, Forsham PH (1973) Lack of glucagon response to hypoglycaemia in diabetes: evidence for an intrinsic pancreatic alpha cell defect. Science 182: 171-173

2. Bolli G, De Feo P, Compagnucci P, Cartechini MG, Angeletti G, Santeusanio F, Brunetti P, Gerich JE (1983) Abnormal glucose counterregulation in insulin-dependent diabetes mellitus: interaction of anti-insulin antibodies and impaired glucagon and epinephrine secretion. Diabetes 32: 134-141

3. Popp DA, Shah SD, Cryer PE (1982) Role of epinephrine mediated beta adrenergic mechanisms in hypoglycemic glucose counterregulation and posthypoglycemic hyperglycemia in IDDM. J Clin Invest $69: 315-326$

4. Boden G, Reichard GA, Hoeldtke RD, Rezvani I, Owen OE (1981) Severe insulin-induced hypoglycemia associated with deficiencies in the release of counterregulatory hormones. N Engl $\mathrm{J}$ Med 305: 1200-1205

5. White NH, Skor DA, Cryer PE, Levandoski LA, Bier DM, Santiago JV (1983) Identification of type 1 diabetic patients at increased risk for hypoglycemia during intensive therapy. $N$ Engl $J$ Med 308: 485-491

6. Multicentre Study (1983) UK prospective study of therapies of maturity onset diabetes. 1. Effect of diet, sulphonylurea, insulin or biguanide therapy on fasting plasma glucose and body weight. Diabetologia 24: 404-411

7. Boden G, Soriano M, Hoeldtke RD, Owen OE (1983) Counterregulatory hormone release and glucose recovery after hypoglycemia in non insulin-dependent diabetic patients. Diabetes 32 : 1055-1059

8. Polonsky KS, Herold KC, Gilden JL, Bergenstal RM, Fang VS, Moosa AR, Jaspan JB (1984) Glucose counterregulation in patients after pancreatectomy: comparison with other clinical forms of diabetes. Diabetes 33: 1112-1119

9. Bolli GB, Tsalikian E, Haymond MW, Cryer PE, Gerich JE (1984) Defective glucose counterregulation after subcutaneous insulin in noninsulin-dependent diabetes mellitus. J Clin Invest $73: 1532-1541$

10. Bennett $T$ (1983) Physiological investigation of diabetic autonomic failure. In: Bannister R (ed) Autonomic failure. A textbook of clinical disorders of the autonomic nervous system. Oxford University Press, Oxford, pp 403-436

11. Bolli GB, DeFeo P, De Cosmo S, Perriello G, Ventura MM, Massa Benedetti M, Santeusanio F, Gerich JE, Brunetti P (1984) A reliable and reproducible test for adequate glucose counterregulation in type 1 diabetes mellitus. Diabetes 33: 732-737

12. Lloyd B, Burin J, Smythe P, Alberti KGMM (1978) Enzymic flourimetric continuous-flow assays for blood glucose, lactate, alanine, glycerol and 3-hydroxybutyrate. Clin Chem 24: 1724-1729

13. Stout RW, Henry RW, Buchanan KD (1976) Triglyceride metabolism in acute starvation: the role of secretin and glucagon. Eur $\mathbf{J}$ Clin Invest 6: 179-185

14. O'Hare MMT, Daly JG, Buchanan KD (1983) Radioimmunoassay for pancreatic polypeptide, and it's age-related changes in concentration. Clin Chem 29: 1923-1927

15. Hales CN, Randle PJ (1963) Immunoassay of insulin. Biochem J 88: 137-146

16. Macdonald IA, Lake DM (1985) An improved technique for extracting catecholamines from body fluids. J Neurosci Methods 13: $239-248$
17. Heding LG (1975) Radioimmunological determinations of human C-peptide in serum. Diabetologia 11: 541-554

18. Ambler J, Walker G, Janik B (1983) Measurement of glycosylated haemoglobin on cellulose acetate membrane. Clin Chem 29: $240-243$

19. Genstat (1980) A General Statistical Program. Rothamstead Experimental Station. Numerical Algorithms Group Ltd, Oxford

20. Reynolds C, Molnar GD, Horwitz DL, Rubenstein AH, Taylor WF, Jiang NS (1977) Abnormalities of endogenous glucagon and insulin in unstable diabetes. Diabetes 26: 36-45

21. Campbell LV, Kraegen EW, Meler H, Lazarus L (1979) Hormonal responses to insulin infusion in diabetes mellitus. Diabetologia $16: 359-364$

22. Levitt NS, Vinik AI, Sive AA, Child P, Jackson WPU (1979) Studies on plasma glucagon concentration in maturity-onset diabetics with autonomic neuropathy. Diabetes 28: 1015-1021

23. Cryer PE, Gerich JE (1985) Glucose counterregulation, hypoglycemia, and intensive insulin therapy in diabetes mellitus. $N$ Engl J Med 313: 232-241

24. Campbell LV, Kraegen EW, Lazarus L (1977) Defective blood glucose counter-regulation in diabetics is a selective form of autonomic neuropathy. Br Med J 2: 1527-1529

25. Maher TD, Tanenberg RJ, Greenberg BZ, Hoffman JE, Doe RP, Goetz FC (1977) Lack of glucagon response to hypoglycaemia in diabetic autonomic neuropathy. Diabetes 26: 196-200

26. Samols E, Weir G, Bonner-Weir S (1983) Intra-islet insulin-glucagon-somatostatin relationships. In: Lefebvre PJ (ed) Handbook of Pharmacology. Glucagon II, Springer, Berlin Heidelberg New York, pp 133-173

27. Unger RH (1983) Insulin-glucagon relationships in the defence against hypoglycaemia. Diabetes 32: 575-583

28. Bolli G, De Feo P, Perriello G, De Cosmo S, Compagnucci P, Santeusanio F, Brunetti P, Unger RH (1984) Mechanisms of glucagon secretion during insulin-induced hypoglycaemia in man. Role of the beta cell and arterial hyperinsulinemia. J Clin Invest 73: 917-922

29. Buchanan KD, Mawhinney WAA (1973) Glucagon release from isolated pancreas in streptozotocin treated rats. Diabetes 22: $797-800$

30. Samols E, Harrison J (1976) Intraislet negative insulin/glucagon feedback. Metabolism 25 (Suppl 1): 1443-1447

31. Berk MA, Clutter WE, Skor D, Shah SD, Gingerich RP, Parvin CA, Cryer PE (1985) Enhanced glycemic responsiveness to epinephrine in insulin-dependent diabetes mellitus is the result of the inability to secrete insulin. J Clin Invest 75: 1842-1851

32. Levitt NS, Vinik AI, Sive AA, Van Tonder S, Lund A (1980) Impaired pancreatic polypeptide responses to insulin induced hypoglycaemia in diabetic autonomic neuropathy. $\mathrm{J}$ Clin Endocrinol Metab 50: 445-449

33. Gray DE, Lickley HLA, Vranic M (1980) Physiologic effects of epinephrine on glucose turnover and plasma free fatty acid concentrations mediated independently of glucagon. Diabetes 29: 600-608

34. Schwartz TW (1983) Pancreatic polypeptide: a hormone under vagal control. Gastroenterology 85: 1411-1425

35. Sive AA, Vinik AI, Levitt N, Van Tonder S (1980) Adrenergic modulation of human pancreatic polypeptide (hPP) release. Gastroenterology 79: 665-672

Received: 25 May 1987

and in revised form: 20 October 1987

Dr. S. R. Heller

Department of Medicine

C Floor, South Block

University Hospital

Queen's Medical Centre

Nottingham NG7 $2 \mathrm{UH}$

UK 